\title{
The role of research to shape local and global engagement
}

\section{CHEPS WORKING PAPER 06/2017}

\author{
Paul Benneworth. CHEPS (University of Twente) \\ p.benneworth@utwente.nl
}

This working paper is the pre-submission version of the paper appearing in this report: GUNi (2017). Higher Education in the World 6. Towards a Socially Responsible University: Balancing the Global with the Local. The report is available via this link: http://www.guninetwork.org/files/download full report.pdf

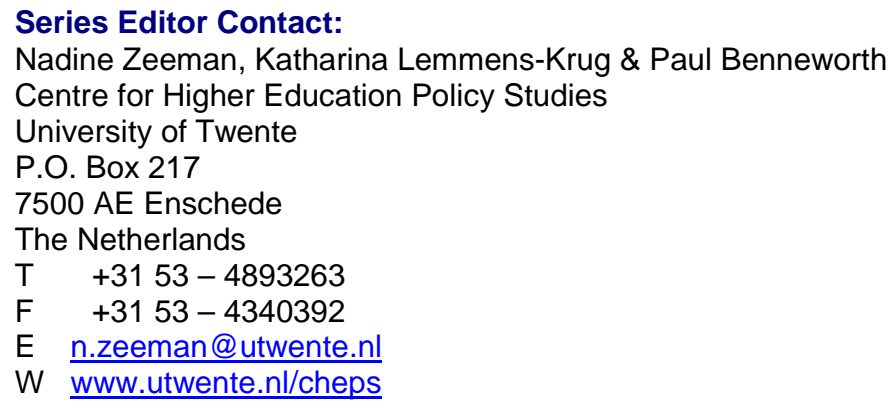




\section{Table of Contents}

Abstract 3

Key ideas in the working paper 4

1. Introduction 6

2. University social responsibility vs the socially responsible university.....................................

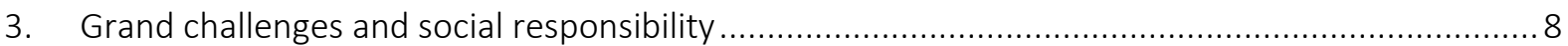

4. Models for engaging citizens in designing responsible research programmes ........................10

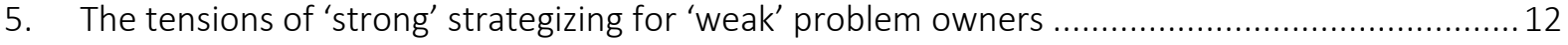

6. From strategic engagement towards empowering engagement change makers .................... 13

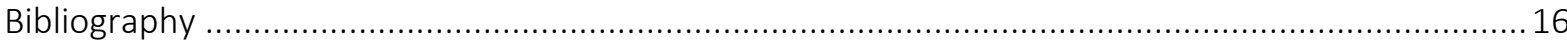




\begin{abstract}
University research has the potential to help solve the grand challenges of the $21^{\text {st }}$ century through local and global engagement. Universities are quintessentially socially engaged institutions that have been supported by external patrons because their activities are socially useful, and that has expanded recently in the context of an emerging global knowledge society. The rise of the Grand Challenges and the adoption by the UN of their sustainable development goals as the overarching societal development challenge for humanity provide a clear articulation of how university research must be responsive to and responsible for creating the necessary knowledge base to solve these challenges. There are a range of emerge models of engaging with citizens locally to allow them to express the ways these problems impact upon their local communities to universities as a first step in the research necessary to solve those problems. But there is a risk in trying to upscale these activities into strategic university goals in crowding out. It is university scholars engaged with communities that will deliver improved local engagement, and universities need to find ways to empower these engaged scholars to stimulate their societal contributions, not creating elaborate internal structures and global networks.
\end{abstract}

Key words: Responsible Research \& Innovation, Socially relevant research, University Engagement, University Third Mission, University Societal Compact 


\section{Key ideas in the working paper}

1. University research offers a substantial knowledge resource that can contribute to solving the UN's Sustainable Development Goals.

2. Using university knowledge to address the UN SDG's requires getting beyond simplistic models of universities as knowledge producers to understanding how universities receive, interpret and respond to local community signals

3. Universities are under pressure to do more than just demonstrate their social responsibility in teaching and research and to develop specific activities to help address the current grand challenges.

4. Universities often become involved in solutions that mitigate and displace particular solutions that benefit powerful entrenched interests rather than contributing to wider processes of societal transition.

5. A key challenge for universities in supporting the global societal transition is therefore in helping create new kinds of social structure and organisational form as well as new technological innovations to these problems

6. Universities therefore need to become better at hearing the voices of the problem owners affected by local manifestations of these global solutions in planning, executing and transmitting their research activities.

7. The key university agent in hearing these voices are engaged scholars who understand how to both work with and on the problems of excluded communities and to use this to enrich their own research and teaching activities within various university contexts

8. There are already many exciting models that exist that can be used to support and expand involving societal problem owners in scientific decision-making and thereby improving the usefulness of the resultant solutions.

9. Pressure on universities to demonstrate their societal relevance is pushing universities towards embracing strategic, high-level, structural approaches to community engagement that risk crowding out the voice of the marginalised problem-owner

10. Any university wanting to be engaged must 'first do their engaged staff no harm': resist the impulse to make structural changes, strategic declarations and global 
networks and rather to increase their engaged scholars' internal influence, recognition and capacity. 


\section{Introduction}

The HEIW 6 report is launched amid increasing pressure on universities to improve their societal contributions to realise the potential amidst growing expectations across society. University research offers a substantial knowledge resource that can contribute to solving the UN's Sustainable Development Goals. These expectations are expressed through several new engagement models seeing close, dynamic interactions between universities, government, business and society. There are two main model variants: the 'Mode 2' model regards science and innovation as shifting from separating research and exploitation in universities and business respectively to universities and businesses solving mutual problems collaboratively (Gibbons et al, 1994). The 'Triple Helix' model argues these partnerships also rely on their capacity to intermediate and address emerging barriers and obstacles to collaboration (Etzkowitz \& Leydesdorff, 2000). Several critiques see these models as missing societal input: Hazelkorn (2011) proposes a Mode 3 model based upon maximising social and public accountability, whilst Leydesdorff argues (2012) for Quadruple Helix models incorporating societal partners.

These models argue that this paradigm shift demands universities develop structurally better connections to a wide spectrum of societal groups both locally and globally, an argument central to this volume. Universities have often regarded this as a structure problem of aligning their researchers more clearly with these problems, but this perception ignores the paradox that directing researchers centrally to work on predefined 'societally-useful topics' stops those researchers from hearing the true voices and demands of the problem-sufferers (Greenwood, 2007). These groups are often sociallyexcluded and marginal groups unable organisation to place their problems on strategic research agendas (Benneworth, 2013a), so hearing their voices requires a step-change in how universities understand marginal social actors roles in creating societally usable knowledge. I argue that universities need build strong dialogues with local excluded communities as problem-owners within these grand challenges, and use these dialogues to allow the communities real, deep-seated and meaningful influence upon universities' developing strategic agendas within their wider global knowledge networks. Using university knowledge to address the UN SDG's requires getting beyond simplistic models 
of universities as knowledge producers to understanding how universities receive, interpret and respond to local community signals

\section{University social responsibility vs the socially responsible university}

Universities are intrinsically societal institutions. As Biggar notes

"Right from their medieval beginnings, [universities] have served private purposes and practical public purposes as well as the sheer amor scientiae ['knowledge for knowledge's sake']...popes and bishops needed educated pastors and they and kings needed educated administrators and lawyers capable of developing and embedding national systems" (Biggar, 2010, p. 77).

But these private sponsors are often uninterested in preserving the long-term knowledge corpus necessary for these immediately useful outcomes. Outcomes useful in the shortterm depend on the existence of a long-term usable knowledge base, and contends that is why historically technical colleges (centres of short-term vocational knowledge) are more likely to evolve into universities (with their long-term general knowledge base) than vice versa (Collini, 2011). This is not a new situation:

"No modern university has ever lived entirely from the sale of its services.

Universities have received subsidies from the church, the state, and private philanthropists as individuals and as foundations" (Shils, 1988, p. 210).

The special subsidies are validated by a societal compact by which universities accept wider societal responsibilities in return for being granted freedoms to preserve and develop the knowledge corpus represent a societal compact (Barnett, 2000). But something has recently changed in this compact, and that is the urgency and immediacy of the pressure: universities previously could validate fulfilling their societal responsibilities through their existing teaching and research activities, similar to firms demonstrating their corporate social responsibility. But today universities face active pressure from governments to demonstrate that they are actively intervening and using strategic management to maximise their societal benefits they create, actively demonstrate compliance beyond teaching and research. 
Universities are under pressure to do more than just demonstrate their social responsibility in teaching and research and to develop specific activities to help address the current grand challenges. The problem with CSR is that promotes demonstrating compliance with 'responsible behaviours' rather than challenging underlying undesirable corporate practices. And recent scandals in Bangladeshi clothing or Chinese electronic subcontracting industries demonstrate, even accredited compliance offers no guarantee of dignified workplaces. And just as glowing corporate CSR reports can exist alongside human rights abuses, under contemporary governmental pressure university engagement can collapse into a reporting practice justifying public support totally disconnected from underlying university ethoses. A simple call for more active reporting by universities therefore risks encouraging universities to develop strategies and structures to validate their existing practices's socially responsibility rather than making practices more engaged - the slipperiness of social responsibility. If universities are serious, they must go further than reporting on practice, demonstrating how their practices creating capacities for societies to do more of the things that they like (Corea, 2007). A key challenge for universities in supporting the global societal transition is therefore in helping create new kinds of social structure and organisational form as well as new technological innovations to these problems.

\section{Grand challenges and social responsibility}

To bridge from university social responsibility to universities making a difference, we reflect on how universities have responded to the grand challenges of the 21st century. Since the Limits to Growth report (Meadows, 1972), a range of temporary fixes have been found to individual problems such as acid rain or pesticide pollution, but those problems' underlying causes have not been addressed. Solving symptoms provides brief respite but also generates new problems, such as the energy transition creating new kinds of energy poverty by those unable to afford the new technologies (Weisz \& Steinberger, 2013). Whilst university knowledge has been well integrated into particular temporary fixes, it has been much less involved in these fundamental societal transitions processes which demand changing societal power relationships (Benneworth \& Cunha, 2015). 
Universities contribute to stimulating these broader transition processes would meet the threshold for genuinely socially responsible behaviour. Ackoff (1999) famously described the grand challenges as "multidisciplinary messes", deep-seated and persistent problems which can only be solved by deploying a range of knowledges drawn from a variety of disciplinary backgrounds simultaneously to solve societal problems. Universities clearly face problems in addressing the grand challenges in joining up between different disciplinary backgrounds spread across university research centres and departments. Good research engagement practice is increasingly recognising the value of creating problem- and challenge-driven research centres (Gooddard \& Vallance, 2013). But I here want to raise a rather unpopular question, of just whose problems are these multidisciplinary centres addressing, and whether that is 'societally responsible'? In particular, this approach presupposes that the problems in society are also problems of society and can be solved by scientific-technological innovations.

Universities often become involved in solutions that mitigate and displace particular solutions that benefit powerful entrenched interests rather than contributing to wider processes of societal transition. Many societal problems emerge through new technology introduction, particularly where that brings unevenly distributed costs and benefits (Oosterlynck \& Swyngedouw, 2010; Davoudi \& Brooks, 2012). In the 1970s strong social movements emerged to shape and democratise technological change to minimise resultant societal problems (Rip \& Schot, 2002). But contemporary approaches lose this, for example so-called "smart city" approaches focusing exclusively on data and technological infrastructure at the expense of people living in places (Velderman, et al, 2017). There is an increasing gulf between the more socially excluded groups who face the costs of the Grand Challenges, whilst policy and infrastructure consortia are primarily concerned in delivering particular technology investment programmes.

There is much talk of 'smart meters' solving the sustainable energy challenge, allowing citizens to modify their consumption and also sustainably generating their own electricity and selling it back into the grid. But this approach reduces a set of real problems, including the pollution blight of those living near coal power stations, and energy exclusion of extreme low income families, literally to a 'black box' technological fix. How can we bring back the people - and their problems - back into these technological developments and ensure their voices are heard in solving societal 
challenges? What roles can universities play in aligning scientific progress more clearly with societal problem-owners' needs and desires, rather than with powerful, wellorganised and elite interests? Universities therefore need to become better at hearing the voices of the problem owners affected by local manifestations of these global solutions in planning, executing and transmitting their research activities.

\section{Models for engaging citizens in designing responsible research programmes}

This challenge of including social problem owners' voices of is certainly not impossible to address for universities at the level of the individual project. In the UK, we see the University of Brighton's Community-University Partnership Programme providing a lowthreshold access to university research group resources and contribute to building up social capital in excluded communities. Having run now for more than a decade, the CUPP helps raise the overall responsibility of the University of Brighton's research and innovation activities are more responsible (Hart \& Aumann, 2013). In Canada, the Community University Research Alliance programme has helped build long-standing local knowledge communities bridging research and practice where societal partner's voices were well-heeded (Garrett-Petts \& Nash, 2012). The science shop model is an example of how students and small-scale projects can intermediate between universities and communities and communities to shape university decision-making (Schlierf \& Meyer, 2013). Norquest College, Edmonton, Canada, developed the "1000 women model" approach which aims to create an endowment fund to support vulnerable women through difficult life moments that might jeopardise their education. The UK's National Co-ordination Centre for Public Engagement has been active in helping academics engage with the public in their research and also teaching activities since 2009.

Arguably, the best models emerge in the Global South, and particularly in Latin America, which has long stressed universities' duties to work with society's less powerful groups, and in increasing measure also in Africa. In many cases, the focus is placed on working with marginalised groups in ways that strengthen their core economic activities and also 
improve their access to education, in ways that fit with the emerging paradigm of social innovation (Edwards-Schachter et al, 2012). The Interdisciplinary Research Programme on Human Development at the Autonomous Metropolitan University, (UAM) Mexico City emerged in its campus at Xochimilco, Chiapas in response to the indigenous peoples' uprising in 1994 (Ramirez, 2011). Garcia \& Carlotto (2012) document how the University of Sao Paolo created a new campus in a deprived area in the east of the city in an attempt to boost enrolments and provide access to research-led education for all. The University of Cape Coast, Ghana, has created the Yamoransa Social Laboratory with support of the Alumni of Yale Association to identify and deliver research solutions to problems in a community setting. In an unusual example of north-south idea, flow, the Instituto Federal de Santa Catarina in Brazil has implemented Norquest College's 1000 women model in three of its campuses to support the national government plans to reduce social exclusion and poverty (Juliani, 2016).

In each of these models, societal voices, representing the social problem owners, participate in knowledge-creation, and hence contribute to shaping the direction of scientific progress in ways that contribute to responsible research and innovation. It is very currently fashionable to talk about co-creation and citizen science methodologies as helping to guarantee citizens can shape the evolving agenda. Our concern lies in that citizens - as owners of these complex socio-scientific problems - are involved in exclusively peripheral and downstream ways that marginalise their interests. What was so exciting about the CURAs in Canada that they aimed to involve societal problem owners in other kinds of research decision-making, around project planning and dissemination (Benneworth \& Jongbloed, 2009). In at least one case it was the community problem-owners who proposed the Research Alliance and therefore were able to frame the research agenda around a community perception of the problem (Kischkuk 2003). The key university agent in hearing these voices are engaged scholars who understand how to both work with and on the problems of excluded communities and to use this to enrich their own research and teaching activities within various university contexts. And there is the risk in moving to institutionalise these good practice models of community engagement and build wider global networks of engaged institutions that the pressure is placed on universities to look to primarily academic interests and partners and regard the problem-owners as beneficiaries rather than full partners. Therefore, the challenge for using research to shape responsible local 
engagement is in making these engagement activities more central to institutional practice without completely obscuring particular local practices that help address issues faced by local problem owners.

\section{The tensions of 'strong' strategizing for 'weak' problem owners}

At the heart of co-creation as a form of scientific research is that it involves the community meaningfully in project execution, influencing the evidence that is unearthed and the theories that are developed to explain it (Hegger et al, 2012). Citizen-scientists are involved in scientific decision-making in an involved, informed way, far from the fear voiced by many scientists that decisions on their research are taken by uninformed and often prejudiced outsiders. And it is precisely this involvement of the societal problemowners at every stage of decisions that shape the course of that research is the greatest strategic challenge for universities in ensuring that they strategically deliver responsible research and innovation. It is only in rare moments that an enlightened authority like Canada's Social Sciences and Humanities' Research Council decides to endow these problem-owners with substantial resources that universities really regard the communities as serious stakeholders and partners. Given the mission overload facing universities, the resource scarcity and competition they face, university strategic structures all too often can lose focus on the local and particular in favour of the global and the excellent. In such circumstances, although universities may extol the virtues of engagements they may create environments which hinder and make marginal the kinds of engagement activities by which university research drives the solving of these problems.

Delanty (2002) has argued that high-level visions of universities' contributions to society have become increasingly individualised, seeking to imbue individuals with the necessary skills for resilience and self-reliance in risk societies. Universities facing competition for students responded increasing use of strategic management techniques, to be driven by a strengthened managerial core (university senior managerial teams) with powers to take strategic decisions. Universities develop strategic agendas to compete, highlighting strengths and opportunities, allocating resources and directing internal decision-making towards collectively pursuing these goals. Universities develop 
strategic relationships with other partners who can contribute different kinds of resources to the university strategic effort, what Jongbloed et al (2007) call universities' strategic stakeholders. Universities therefore seek to align their research efforts with those who have appropriate resources for strengthening university research activities whilst also delivering for those external stakeholders.

As long as the problem-owners are the same as the university strategic stakeholders, then this strategic alignment will ensure that university research effort contributes to solving grand societal challenges. But with grand challenges, the problem owners are socially excluded communities (Byrne, 1999) who bear the costs of these technological problems and often experience neither the benefits that the problems bring nor are their recipients of mitigation and amelioration interventions. If your salience to universities as a strategic stakeholder depends on your resources to contribute to university research efforts, then excluded communities can never be salient (cf CERI, 1982). Communities lack financial resources to support new activities, they lack sufficient internal cohesion and political strength to provide legitimacy for university activities, and the kinds of knowledge they possess are typically very localised, applied and specific rather than immediately applicable to world-class excellent research. Certainly, these excluded communities have much less scope to function as equal partners co-determining research agendas as university researchers take decisions around whose problems are worth their attention.

\section{From strategic engagement towards empowering engagement change makers}

Pressure on universities to demonstrate their societal relevance is pushing universities towards embracing strategic, high-level, structural approaches to community engagement that risk crowding out the voice of the marginalised problem-owner. Within universities, there are all kinds of structures and mechanisms that devalue and downgrade those undertaking research with excluded communities, relating to seniority, promotion, tenure, stability and span of control (Humphrey, 2013). There is the very real risk that strategies become focused on the most powerful stakeholders, and ignore these problematic problem owners, with the result that their research becomes less 
responsibly developed. The best models under such circumstances are therefore those that attempt to empower university knowledge communities to engage on more equal terms with these societal problem owners, and to situate that localised community knowledge within wider global networks of more generalised, academic knowledge.

And what determines how successful the university is in making a real contribution to solving these communities' problems are the university academic staff who find a way to listen to and include community voices as a positive, constructive resource throughout their research processes. So whilst the ten examples given above are interesting projects that can help use research to drive engagement, they are all ad hominem models dependent upon those engaged, open researchers. Universities need to find ways to let their engaged scholars engage in processes of "institution entrepreneurship" (Benneworth et al, 2016) that remake the institution as more engaged, supported by university senior managers. Through a process of university leaders signalling that they substantively value their engaged scholars, the university becomes a more engaged institution.

Community engagement, and working with the real problem owners, sits extremely uneasily with strategic approaches to university management. The UK's National Coordinating Centre for Public Engagement experimented with a structural centre approach to stimulating university-community engagement but more recently has reverted to supporting individuals rather than building structures. University-community engagement is dependent upon ensuring that 'one thousand flowers may bloom at one' whilst university strategic management invests university leaders with super luminary characteristics to singularly determine a 'strategic course' for the university.

Although the recent enthusiasm for making universities more responsible and engaged is to be welcomed, there is a prima facie fear that this may lead universities in practice to do more to make lives only more difficult for their engaged scholars. It is important that universities under increasing pressure do not therefore take action at the strategic level, to build up global partnerships and improve knowledge exchange, that reduce their engaged scholars' capability to listen, observe, and respond positively to local problem owners. And given this fear, it is worth highlighting the range of 'strategic management' interventions that might seem appealing for managers to better connect their research to 
local and global engagement but in reality will only make lives harder for their engaged researchers. Any university wanting to be engaged must 'first do their engaged staff no harm': resist the impulse to make structural changes, strategic declarations and global networks and rather to increase their engaged scholars' internal influence, recognition and capacity (see box below).

\section{0 impressive sounding strategic interventions university managers can make that will}

hinder their change agents and engagement stars

1. Appoint a senior manager for engagement (because the best candidates for the job prefer to stay doing their engaged research)

2. Create a 'one-stop shop' for community engagement and social innovation (because it comes 'someone else's responsibility).

3. Develop a strategy for engagement and global challenges (because then the document becomes an end in itself).

4. Adopt Key Performance Indicators for global engagement activities (because you can't ever measure what really matters to your desired outcomes)

5. Assemble a Board of Key Stakeholders to identify how the university can contribute (because the real problem-owners are too busy for your board)

6. Agree a set of high level Global Challenges that your institution agrees to address (because agreement demands they be so meaningless in practice)

7. Require every research unit to report on how they are solving Grand Challenges (because then reporting not action becomes the goal).

8. Create a promotion pathway for socially engaged researchers and teachers (because that doesn't make promotions panels more likely to value their engaged practices)

9. Join a Global Partnership network for solving grand challenges (because that network will never overlap with the interactions your engaged researchers really need)

10. Bring the leading engaged teachers and researchers together in a focus group or engagement unit (because your institutional entrepreneurs are already busy enough).

In principle, it is possible for universities to serve as a pivotal link between global academic knowledge communities and local problem-owners, but this comes with an inherent imbalance in the respective priorities that universities accord these scales. The strategic approach always brings a risk that universities work for the global, and see local partners as a resource to be harvested for competitive advantage. Even the most dedicated and sincere institutions in cultures with long traditions of universitycommunity engagement report substantive problems including excluded communities as problem owners in their strategic decision-making. It is clearer now than ever that this is a challenge that we must take seriously and not simply address with more of the same of globally-facing strategic management. Without strong local dialogues and engagement shaping university strategic decisions, university research will remain at a disadvantage 
in its endeavours to contribute meaningfully to solving the real grand challenges currently facing humanity.

\section{Bibliography}

Agyeman, J. (2014). Global environmental justice or Le droit au monde?. Geoforum, 54, 236-238.

Barnett ,R. (2000) “Realising a compact for higher education” in K. Moti Gokulsing \& C. DaCosta (eds) A compact for higher education, Aldershot, Ashgate.

Benneworth, P. (2013a) “University Engagement with Socially Excluded Communities”; in P. Benneworth (ed.) University engagement with socially excluded communities, Dordrecht, Springer.

Benneworth, P. (2013b) “The relationship of community engagement with universities' core missions" in P. Benneworth (ed.) University engagement with socially excluded communities, Dordrecht: Springer.

Benneworth, P., \& Cunha, J. (2015). “Universities' contributions to social innovation: reflections in theory \& practice”, European Journal of Innovation Management, 18(4), pp. 508-527.

Benneworth, P. \& Jongbloed, B.W.A (2009) "Who matters to universities? A stakeholder perspective on humanities, arts and social sciences valorisation" Higher Education DOI $10.1007 / \mathrm{s} 10734-009-9265-2$

Benneworth, P. S. Pinheiro, R. \& Karlsen, J. (2016) “Strategic Agency and Institutional Change: Investigating the Role of Universities in Regional Innovation Systems (RISs)" Regional Studies (in press).

Biggar, N. (2010) “What are universities for” Standpoint 24, pp. 76-79.

Burrows, J. (1999), Going beyond labels: a framework for profiling institutional stakeholders, Contemporary Education, Vol. 70, No. 4, pp. 5-10.

Buzzelli, M., \& Jerrett, M. (2004). Racial gradients of ambient air pollution exposure in Hamilton, Canada. Environment and planning A, 36(10), 1855-1876.

Byrne, D. (1999) Social Exclusion, Buckingham, Open University Press.

Centre for Educational research and innovation (1982) The university and the community: the problems of changing relationships, Paris: OECD

Collini, S. (2011) What are universities for?, London, Penguin. 
Corea, Stephen. "Promoting development through information technology innovation: The IT artifact, artfulness, and articulation." Information Technology for Development 13.1 (2007): 49-69.

Davoudi, S. \& Brooks, L. (2012) Environmental justice and the city Durham: Institute of Local Governance. $<$ Accessed 25th November 2012><Available on-line at http://www.ncl.ac.uk/socialrenewal/fairnesscommission/documents/environmentaljustice-and-the-city.pdf> Etzkowitz, Henry, and Loet Leydesdorff. "The dynamics of innovation: from National Systems and "Mode 2" to a Triple Helix of university-industrygovernment relations." Research policy 29.2 (2000): 109-123.

Delanty, G. (2002) 'The university and modernity: a history of the present', in Robins, K. and Webster, F. The Virtual University: Knowledge, Markets and Management, OUP, Oxford.

Edwards-Schachter, M. E., Matti, C.E. \& Alcantara, E. (2012) "Fostering quality of life through social innovation: a living laboratory methodology study case' Review of Regional Policy Research, 29 (6) pp. 672-692.

Garcia, S. G. \& Carlotto, M. C. (2013) "Institutional Specificity and Organizational Change A Case of University Social Engagement in Brazil" in in R. Pinheiro, P. Benneworth and G. Jones (eds.), Universities and Regional Development. A Critical Assessment of Tensions and Contradictions. New York: Routledge

Garrett-Petts, W. F., \& Nash, R. (2012). Making Interdisciplinary Inquiry Visible: The Role of Artist-Researchers in a Ten-Year Community-University Research Alliance. International Journal of the Arts in Society, 6(5).

Gibbons M, Limoges C, Nowotny H, et al. (1994). The new production of knowledge: The dynamics of science and research in contemporary societies. London: Sage.

Goddard, J. \& Vallance, P. (2013). The university and the city, London: Routledge.

Greenwood, D. (2007) "Who are the real problem-owners" in A. Harding, A. Scott, S. Laske \& C. Burtscher (eds) Bright satanic mills: universities, regional development and the knowledge economy, Aldershot: Ashgate

Hart, A., \& Aumann, K. (2013). Challenging Inequalities Through Community-University Partnerships. In University engagement with socially excluded communities (pp. 47-65). Springer Netherlands.

Hazelkorn, E. (2011) Ranking and the reshaping of higher education: the battle for world-class excellence, London: Plagrave Macmillan

Hegger, D., Lamers, M., Van Zeijl-Rozema, A., \& Dieperink, C. (2012). Conceptualising joint knowledge production in regional climate change adaptation projects: success conditions and levers for action. Environmental science \& policy, 18, 52-65.

Humphrey, L. (2013) University-Community Engagement: Dislocation of Theory and Practice, in P. Benneworth (ed.) University engagement with socially excluded communities, Dordrecht, Springer. 
Jongbloed, B. Enders, J \& Salerno, C. (2007) "Higher education and its communities: interconnections, interdependencies and a research agenda" Higher Education, 56 (3) pp 303-324.

Juliani, D. Tamilis da Silva, A. Cunha, J. \& Benneworth, P. (2016) “Insights from a case study on social innovation" paper presented to Regional HELIX conference, 29th June - 1st July 2016, Castelo Branco, Portugal.

Kishchuk, N. (2003) "Performance report: phase 1of the Community University Research Alliances programme”, Ottowa: SSHRC (Canada).

Leydesdorff, Loet. "The triple helix, quadruple helix,..., and an n-tuple of helices: explanatory models for analyzing the knowledge-based economy?."Journal of the Knowledge Economy 3.1 (2012): 25-35.

Meadows, D., Randers J. and Behrens III W. (1972), The Limits to Growth, London, Pan Books. Shils, E. (1988) "The university, the city and the world: Chicago and the university of Chicago" in: T. Bender (ed.), The University and the City. From Medieval Origins to the Present. New York/Oxford: Oxford University Press pp. 210-229.

Oosterlynck, S., Swyngedouw, E. (2010) "Noise reduction: the postpolitical quandary of night flights at Brussels airport". Environment and planning A,42(7), 1577-1594.

Powell J. \& Dayson, K. (2013) Engagement and the Idea of the Civic University in P. Benneworth (ed.) University engagement with socially excluded communities, Dordrecht, Springer.

Ramirez, A. S. (2011). "The role of universities in promoting rural innovation in Latin America." Regional Insights, 2(1), 24-25.

Rip, A.; Schot, J.W. (2002) "Identifying loci for influencing the dynamics of technological development", in Sorensen, K. and Williams, R. (Eds.) Shaping technology, guiding policy: Concepts, spaces \& tools. Edward Elgar, Cheltenham, UK.

Schlierf, K., \& Meyer, M. (2013). Situating knowledge intermediation: Insights from science shops and knowledge brokers. Science and public policy, sct034. Science and Public Policy (2013) 40 (4): 430-441.

Velderman, W. J., Eckardt, F., \& Benneworth, P. S. (2017) Knowledge, policymaking and participation: a democratic challenge, in N. Dotti "Knowledge policy-making and learning for European Regions and Cities (ed.) London, Edward Elgar.

Weisz, H., \& Steinberger, J. K. (2010). Reducing energy and material flows in cities. Current Opinion in Environmental Sustainability, 2(3), 185-192. 
The Center for Higher Education Policy Studies (CHEPS) is a research institute (WHW, Article 9.20) located in the Faculty of Behavioural and Management Sciences within the University of Twente, a public university established by the Dutch government in 1961. CHEPS is a specialized higher education policy centre that combines basic and applied research with education, training and consultancy activities.

Center for Higher Education Policy Studies 